\title{
A comment on the multifaceted relationship between multinational enterprises and within-country inequality
}

\author{
Rajneesh Narula \\ Henley Business School, University of Reading, \\ Henley-on-Thames, Oxfordshire, UK, and \\ Khadija van der Straaten \\ Amsterdam Business School, University of Amsterdam, Amsterdam, \\ The Netherlands
}

\begin{abstract}
Purpose - Whether by direct or indirect action (or by inaction), multinational enterprises (MNEs) can have both a positive and a negative effect on within-country social and economic inequality. This paper aims to comment on this multifaceted relationship between MNEs and within-country inequality.

Design/methodology/approach - Given the absence of either robust theory or evidence in the neglected realm of MNEs and within-countries inequalities, this paper offers some general observations, highlights some of the key issues and illustrates possible avenues for future research studies.

Findings - The capacity of MNEs to upgrade economic activity in the host country is a key policy objective MNEs have arguably contributed to reducing income inequalities between countries. However, the limited evidence available suggests that the gains of FDI are rarely evenly distributed within recipient countries, and many of the underlying dynamics need further investigation.

Social implications - The authors broaden the engagement with inequality beyond income levels, as this is just one aspect of inequality that shapes or impedes human development. They believe it is necessary - for both MNEs and policymakers - to have a more nuanced understanding of how, and under what circumstances, the presence of MNEs affects inequality in host economies.
\end{abstract}

Originality/value - This paper relates the large literature on inequality (going beyond the mainstream focus on income inequality) to the mainstream understanding of MNE-assisted development.

Keywords Gender, Multinational enterprises, Economic Development, Inequality, Development

Paper type Viewpoint

(C) Rajneesh Narula and Khadija van der Straaten. Published by Emerald Group Publishing Limited. This article is published under the Creative Commons Attribution (CC BY 4.0) licence. Anyone may reproduce, distribute, translate and create derivative works of this article (for both commercial and non-commercial purposes), subject to full attribution to the original publication and authors. The full terms of this licence may be seen at http://creativecommons.org/licences/by/4.0/legalcode

The authors thank the (Special Issue) Editors Marina Papanastasiou and Shasha Zhao for their guidance and constructive comments, which were instrumental to the development of this paper.

This paper forms part of a special section "Do Multinational Enterprises Contribute to, or Reduce Global Inequality?", guest edited by Shasha Zhao, Paul N. Gooderham, Anne-Wil Harzing and Marina Papanastassiou.

Multinational enterprises and within-country inequality

Received 9 July 2019 Revised 1 October 2019 Accepted 15 October 2019 


\section{CPOIB}

17,1

\section{Introduction}

Inequality in its various forms lies at the heart of much of the contemporary discussion on the world economy over the past two decades, arguably best highlighted by the considerable attention in both the popular and academic press to the publication of Piketty (2013). It is by no means a new theme for socio-economic thought, inspiring Adam Smith, David Ricardo and Karl Marx, to name but a few. Indeed, the sources of inequality and possible remedies to the persistence of inequality have exercised the minds of some of mankind's greatest thinkers for several centuries.

The current debate to which we intend to contribute is how the nature and causes of inequality are shaped by economic globalisation (Kobrin, 2017; Kaplinsky, 2013). Globalisation for our purposes is taken to mean the growing cross-border interdependence of markets for goods, services and capital (Narula, 2003), and we narrow our focus even further to the role of the multinational enterprise (MNE) in developing economies characterised typically by substantial informal sectors. MNEs sit at the heart of globalisation, being among the most visible (and tangible) players that shape the crossborder interdependence of economic actors.

The work of Piketty (2013), his associates (Alvaredo et al., 2017) and a wide variety of national and international institutions has consistently pointed to a rising within-countries inequality. This trend has been fairly consistently observed across most countries, and concomitantly, over the last three decades, a period defined by intensifying globalisation (Bourguignon, 2015; Maskin, 2015; Milanovic, 2016). Although there has been little systematic research to indicate that there is a cause-and-effect association between the rising within-countries inequality and the pace of globalisation, the subject is worthy of more systematic examination. The recent contribution of Pearce and Tang (2019) provides a welcome missive in addressing the concomitant (distributional) effects of FDI and the MNE. We underline and amplify his concerns that the gains of FDI are rarely equally distributed between the MNE and the host country, but we go further by offering an equally relevant (and unanswered) question: how do MNEs affect the extant inequalities within a host country? We also seek to broaden scholarly engagement with inequality beyond income levels, which is just one aspect of inequality shaping or impeding human development.

The role of MNEs in inequality has hitherto not been a significant subject for debate in the field of international business (IB). Although the potential of the MNE to impact development more generally was a key preoccupation in the early IB literature[1] (Hymer, 1975; Dunning, 1958, 1981; Lall and Streeten, 1977) the attention to inequality has been somewhat sporadic, largely limited to addressing the nature of inequality between-countries (Narula, 1996; Narula and Dunning, 2000, 2010). Much of this work considers the differences in the aggregate incomes between different countries, the extent to which income levels have converged or diverged relative to each other, and how FDI may have contributed to these changes.

The field of IB has, in any case, increasingly taken a more MNE-centric view of the FDIdevelopment nexus, largely avoiding explicit engagement with development-specific questions (Narula and Pineli, 2019). By and large, the recent literature (in IB and economics) has tended to focus implicitly on how MNEs provide net positive effects for development[2], particularly in the interaction between domestic actors and the MNE. However, there is significant reason, and evidence, to believe that not all outcomes from the participation of MNEs in the economy are positive, or even net positive (Narula, 2019; Kaplinsky, 2013). The degree to which the MNE is complicit in negative development outcomes is contentious and under researched.

It is not universally accepted that firms should have an explicit role in addressing inequality. Indeed, some argue that firms should focus on their primary objective of generating profits. Others feel that firms have a moral responsibility to address development challenges 
(Ünal and Chen, 2017). The view we take in this paper is that MNEs - by direct or indirect action, or by inaction - can be a key source of increased inequalities, not least because they play an outsized and growing role in most developing countries and can have potentially large distributional effects through providing employment and paying wages (Helpman et al., 2008). Thus, we believe it is necessary, for both MNEs and policymakers, to have a nuanced understanding of how, and under what circumstances, the presence of MNEs increases inequality in host economies.

Relating the large literature on inequality (and going beyond the mainstream focus on Multinational enterprises and within-country inequality income inequality) with the scholarly contributions to MNE-assisted development is a novel research direction. Given the absence of either robust theory or evidence in the neglected realm of MNEs and within-countries inequalities, we cannot (and do not) offer more than some general observations, highlighting some of the key issues and illustrating possible avenues for future research.

\section{A brief introduction to within-country inequality}

The increasing disparity of within-country incomes since 1970s has caused a renewed interest in the topic of within-country inequality, with Krugman (2007, p. 124) describing the current trend as the "great divergence". However, it has been the subject of much interest and intellectual speculation since at least the time of Adam Smith. Indeed, since its inception, the field of political economy has been in great part devoted to addressing the means by which society (and governments) might achieve an effective and more equitable redistribution of wealth. Smith (1776) famously believed in the power of markets, arguing that competitive pressures would ultimately act to limit profits and wealth accumulation of firms. He also believed that worker's wages would continue to increase, reflecting their value as a key input to industry:

They who feed, clothe, and lodge the whole body of the people, should have such a share of the produce of their own labour as to be themselves tolerably well fed, clothed, and lodged (Smith, 1776, p 1:8).

According to Smith, an uneven division of wealth between owners/employers and workers could only be explained by bargaining asymmetries between individual employers and employees, and Smith advocated taxes and regulation to correct this problem (Boucoyannis, 2013). Smith's view was surprisingly similar to Marx (1867), who identified exploitation of workers by employers (i.e. the owners of "capital") as the key source of inequality. However, Marx was famously bereft of faith in markets to self-correct the inequities of capitalism. He argued that when workers are systematically exploited (and the state failed to address the imbalance) through adequate counter-measures, such inequalities would continue to increase indefinitely.

Piketty (2013) shares Marx's more pessimistic view, arguing that when the return to capital [3] is higher than the return to labour, inequality between those who possess wealth and those who do not becomes aggravated. Stiglitz (2012) posits that this accumulation of wealth is further amplified by the greater political power that comes with wealth, which is used to shape the economy (and the policies of the state) to the benefit of the wealthy.

While Smith, Marx and Piketty all focus on inequality in income (though Smith only considers income an instrument to alleviate poverty and deprivation), inequality has many dimensions. The work of Sen $(1992,2009)$ takes a much broader canvas, viewing income inequality (and economic measures of development) as one of several aspects of inequality that shape or impede the progress of human development. Sen makes a distinction between inequality in the distribution of a variety of human needs, including the quality of nutrition, access to health care, education, shelter and a variety of other factors. Development is not 
CPOIB 17,1

just about the capacity to maximise income, and underdevelopment is not only about differences in income, but also about the ability of individuals to optimise both the quality of their existence, and their potential. Sen's view is that non-income inequalities matter just as much, and ultimately also further exaggerates income inequality. Initial conditions matter: People have uneven access to a variety of resources due to, for instance, their race, gender or religion. When people are unevenly deprived of the freedom to optimise the quality of their existence, this exacerbates inequalities and acts to impede significant sections of society.

Certain commentators believe that disparities in societies reflect differences in endowments and differences in individual skills, capabilities and cultural attitudes towards work (Cheung and Chan, 2007). These views accept that there is an aspect of luck associated with, for instance, being born to a specific gender, race or location and that success is the fortunate outcome of genetics, upbringing and environment (Hughes, 2018; Krugman, 2016a) and because these circumstances may indeed play a role in determining inequality, extreme levels of inequality are not morally justifiable (Hughes, 2018).

Within-countries inequalities have a fundamental spatial element, in that there are often wide disparities between different locations within countries, whether between regions, or indeed, within cities or towns. The spatial discussion is as old as the debate on the sources of, and solutions to inequality: Why do certain communities fail to prosper, while others do? Economics has a tradition of taking a dichotomous approach to understanding spatial inequality, the two most influential being the core-periphery approach (systematically analysed by Alfred Marshall [1919], and the basis of much of economic geography), and the dual economy model, which views countries taking a rural-urban division (Lewis, 1954). Both approaches address how resources (goods, labour and capital) move across the divide (or fail to do so). The core-periphery scholarship concluded that when there are declining costs of transportation and communication, the resultant increased commerce leads economic activity to re-organise itself along a core-periphery structure, to the benefit of the core (or the urban regions), and the detriment of the periphery (or the rural regions). That is, there a "hollowing out" in the periphery, and an agglomeration of activity in the core, because economic activity will concentrate production where demand is greater, and where economies of scale can be gained (Benito and Narula, 2007). The dual economy in its original formulation was concerned with the flows of surplus labour from low-productivity (resource-intensive) rural locations, to higher productivity (and knowledge-intensive) activities located in urban locations. Later contributions have expanded the Lewisian approach to the informal-formal divide, and the role of firms and technology in facilitating the redistribution from one sector (and location) to another. Both the core-periphery and the dual economy model take the view, however, that the overall economy benefits from this redistribution in the long run. They are largely unhelpful for the policymaker who is interested in curtailing the ensuing inequalities, or is seeking to minimise societal imbalances in the shorter run.

\section{Inequality and development}

The sustainable development goals (SDGs), adopted by all United Nations member states in 2015, encompass the 17 core challenges of global development. One of these core challenges is the reduction of inequality between and within countries (SDG \#10). According to the United Nations (2019) Human Development Report, reducing inequality is a sine qua non to most of the other SDGs and development in general. Eliminating poverty and hunger, improving access to health care, education and sanitation are all unachievable if efforts do not disproportionally benefit the 10 per cent of the world's population who currently receive little to none of the world's income (i.e. less than $\$ 1.90$ a day at PPP). 
The work of Banerjee and Duflo (2007) highlights that it is the lack of access to resources which prevents the poor and deprived from improving their income and overall welfare. Poor nutrition, health care and lack of education are detrimental to productivity and thereby impede access to better-paid (and in some cases, even to subsistence) employment. For instance, a lack of tangible assets, proof of legal ownership or access to the formal banking system limits small and informal actors in society from borrowing money to set up or expand their business (Narula, 2018b, 2019). Most of these exorbitant inequalities take place in developing countries with informal economies playing an outsized role, where the informal sector can account for as much as 80 per cent of the activities. The persistence of the informal sector as the dominant aspect of an economy perpetuates low income levels and limits opportunities for development, thereby sustaining inequality with those who do have access to the formal economy (Narula, 2019; Ravi, 2018; Gradín and Sen, 2019). Moreover, inequality hampers development because it leads to social and political instability (Maskin, 2015), e.g. through increased crime rates, substance abuse and (mental) health problems (Nolan et al., 2014; Wilkinson and Pickett, 2006, 2009a, 2009b), reduced trust (Gustavsson and Jordahl, 2008; Uslaner and Brown, 2005) and reduced social cohesion (Wilkinson, 1999).

In many instances, MNEs have created opportunities for entrepreneurial activity within the informal sector (Pietrobelli and Rabellotti, 2011). The fittest informal enterprises survive and expand towards the formal economy. Supporting the upgrading of the informal economy is key to reducing inequality (Chen, 2012), but most countries lack the capacity to do so. Informality is a major development trap. Individuals and enterprises pay no taxes are unable to seek credit, with no legal rights, and with limited access to public goods. Those trapped in the informal sector tend to be undernourished, less educated with shorter lifespans and fewer opportunities to escape poverty (La Porta and Shleifer, 2008).

Figure 1 offers details on how within-country income inequality has developed over 1983-2017 for several of the world's regions. It is measured by the Gini coefficient, which represents a country's income distribution and is the most commonly used measure of inequality. In a country with a Gini coefficient of zero every person receives the same

\begin{tabular}{|c|c|c|c|c|c|c|c|c|c|c|c|c|c|c|}
\hline \multirow{3}{*}{$\begin{array}{l}\text { Country } \\
\text { India }\end{array}$} & \multicolumn{3}{|c|}{ Inequality (Gini) } & \multicolumn{3}{|c|}{ Youth Literacy (\%) } & \multicolumn{2}{|c|}{ Life expectancy (years) } & \multicolumn{3}{|c|}{ Infant Mortality (per 1000 births) } & \multicolumn{3}{|c|}{ GDP/capita (US\$ ' 000 at PPP) } \\
\hline & 1983 & 2011 & & 1981 & 2011 & & 1983 & 2011 & 1983 & 2011 & & 1990 & 2011 & \\
\hline & 32.1 & 35.7 & $\rightarrow$ & 54 & 86 & 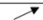 & 55 & 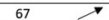 & 106 & 43 & 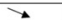 & 1 & 5 & $\rightarrow$ \\
\hline \multirow{2}{*}{ China } & 1990 & 2015 & & 1990 & 2010 & & 1990 & 2015 & 1990 & 2015 & & 1990 & 2015 & \\
\hline & 32.3 & 38.6 & 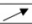 & 94 & 100 & $\pi$ & 69 & 76 & 42 & 9 & $\Delta$ & 1 & 14 & 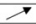 \\
\hline \multirow{2}{*}{ Indonesia } & 1984 & 2017 & & 1989 & 2016 & & 1984 & 2017 & 1984 & 2017 & & 1990 & 2017 & \\
\hline & 32.4 & 38.1 & $\rightarrow$ & 85 & 100 & $\rightarrow$ & 61 & 69 & 76 & 21 & 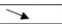 & 3 & 12 & $\rightarrow$ \\
\hline \multirow{2}{*}{ Turkey } & 1987 & 2016 & & 1985 & 2016 & & 1987 & 2016 & 1987 & 2016 & & 1990 & 2016 & \\
\hline & 43.5 & 41.9 & $\boldsymbol{A}$ & 91 & 100 & $\rightarrow$ & 63 & 76 & 64 & 11 & 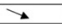 & 6 & 26 & $\Longrightarrow$ \\
\hline \multirow{2}{*}{ Romania } & 1989 & 2015 & & 1992 & 2011 & & 1989 & 2015 & 1989 & 2015 & & 1990 & 2015 & \\
\hline & 23.3 & 35.9 & $\rightarrow$ & 99 & 99 & $\rightarrow$ & 70 & 75 & 26 & 8 & $y$ & 5 & 22 & $\Rightarrow$ \\
\hline \multirow{2}{*}{ Poland } & 1993 & 2016 & & & & & 1993 & 2016 & 1993 & 2016 & & 1993 & 2016 & \\
\hline & 26.7 & 30.8 & 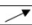 & & & & 72 & 78 & 14 & 4 & $y$ & 7 & 28 & $\rightarrow$ \\
\hline \multirow{2}{*}{ Morocco } & 1984 & 2013 & & 1982 & 2012 & & 1984 & 2013 & 1984 & 2013 & & 1990 & 2013 & \\
\hline & 39.2 & 39.5 & $\pi$ & 44 & 91 & $\pi$ & 61 & $\pi$ & 80 & 24 & $y$ & 3 & 7 & $\rightarrow$ \\
\hline \multirow{2}{*}{ Ghana } & 1987 & 2016 & & 2000 & 2010 & & 1987 & 2016 & 1987 & 2016 & & 1990 & 2016 & \\
\hline & 35.3 & 43.5 & $\rightarrow$ & 71 & 86 & $\rightarrow$ & 55 & $\rightarrow$ & 89 & 37 & 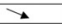 & 1 & 4 & $\rightarrow$ \\
\hline \multirow{2}{*}{ South Africa } & 1993 & 2014 & & 1980 & 2015 & & 1993 & 2014 & 1993 & 2014 & & 1993 & 2014 & \\
\hline & 59.3 & 63.0 & 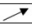 & 85 & 99 & 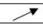 & 62 & 61 & 46 & 33 & 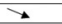 & 6 & 13 & 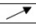 \\
\hline \multirow{2}{*}{ Brazil } & 1981 & 2017 & & 1980 & 2015 & & 1981 & 2017 & 1981 & 2017 & & 1990 & 2017 & \\
\hline & 58.0 & 53.3 & 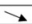 & 84 & 99 & 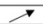 & 62 & $T$ & 74 & 13 & - & 7 & 16 & $\Longrightarrow$ \\
\hline \multirow{2}{*}{ Colombia } & 1992 & 2017 & & 1993 & 2016 & & 1992 & 2017 & 1992 & 2017 & & 1992 & 2017 & \\
\hline & 51.5 & 49.7 & 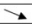 & 95 & 99 & $\rightarrow$ & 69 & $\rightarrow$ & 27 & 13 & 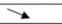 & 5 & 15 & $\Longrightarrow$ \\
\hline \multirow{2}{*}{ Jamaica } & 1988 & 2004 & & 1991 & 2014 & & 1988 & 2004 & 1988 & 2004 & & 1990 & 2004 & \\
\hline & 43.2 & 45.5 & 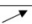 & 92 & 96 & $>$ & 72 & 73 & 27 & 18 & 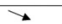 & 5 & 7 & 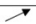 \\
\hline
\end{tabular}

Notes: within-countries inequality is measured by the Gini coefficient, data derived from the World Bank Database and measured over the first and the latest year available; due to data limitations Youth Literacy (percentage of people aged 15-24) is unavailable for Poland. All development indicators are measured over the same period as the inequality indicator, or the closest year available. All development indicators are derived from the World Bank Database

Multinational enterprises and within-country inequality

Figure 1.

Inequality and development indicators, selected countries, 1983-2017

(or closest year) 
CPOIB

17,1

38

Figure 2.

Average national income shares of the $50 \%$ bottom earners income. In a country with a Gini coefficient of 100 , all income is received by one person. As is evident from the scores, little to no progress has been made in terms of reducing inequality within countries. Inequality has risen in many countries in the world, has somewhat diminished in Turkey and Colombia and has diminished but remains high in Brazil.

This lack of progress in terms of reducing within-country inequality is contrasted in Figure 1 with key development indicators that compare development between-countries: Youth literacy, life expectancy, infant mortality and average per capita income. In terms of literacy rates, progress is clearly being made. The same catching-up can be observed for life expectancy in all countries but South Africa. While infant mortality is still relatively high in India and Ghana, a significant improvement of 63 and 52 less deaths per 1,000 births can be observed. GDP per capita also still widely varies by region, but has risen in consistently.

Additionally, Figure 2 shows the share of national income earned by the bottom half of the population across several of the world's regions. It illustrates how the absence of progress in reducing within-country inequality over the past three decades is observed in most regions of the world, with the exception of Latin America where the income share earned by the bottom half of the population has increased but still remains relatively low. Figure 2 also shows that it is not solely the top 1 per cent compared to the other 99 per cent of the population that is causing the more uneven distribution, but also the top half compared to the bottom half of population in terms of income.

Overall, the evidence reviewed here and elsewhere confirms that in terms of health, education and poverty, there have been vast improvements made over the past three decades, suggesting that there has been a convergence in development between countries. However, in terms of the distribution of income within countries, the evidence suggests incomes are diverging rather than converging.

\section{Multinational enterprises as instruments for development}

Throughout the globe, countries are competing to attract FDI in hope of accelerating their economic development. This is based on the underlying assumption that FDI has a positive effect on development, particularly in the interaction between domestic actors and MNEs (Narula and Dunning, 2010). One of the most researched positive effects involves the

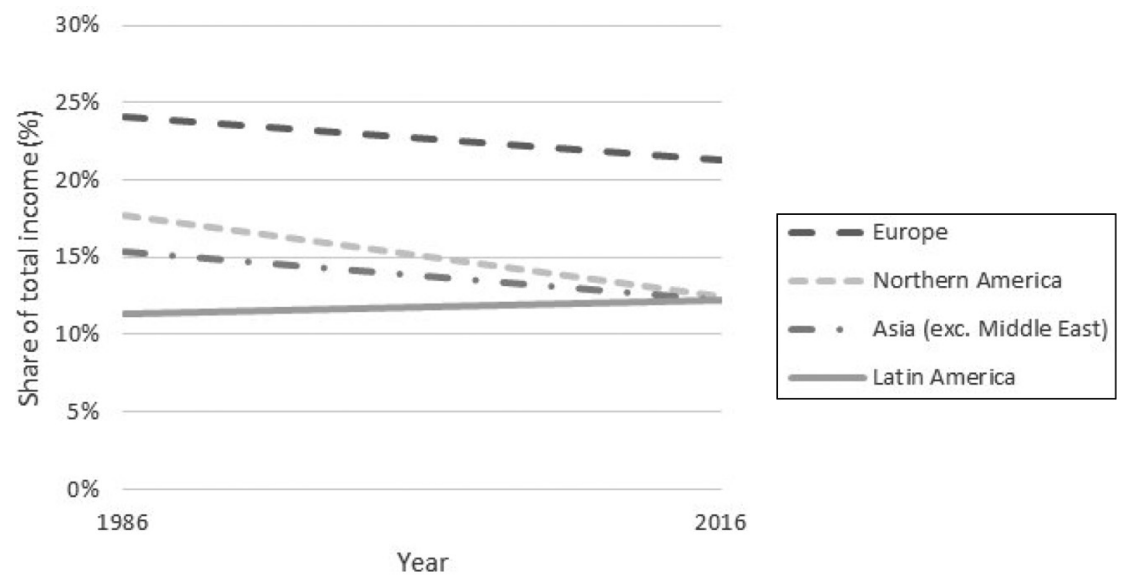

Sources: Authors. Data derived from the World Inequality Database 
potential productivity advances of local firms benefitting from knowledge spill-overs from MNEs' subsidiaries (Altomonte and Pennings, 2009; Buckley et al., 2007; Giroud, 2007; Ha and Giroud, 2015; Meyer and Sinani, 2009). These positive effects arise because MNEs possess firm-specific advantages (FSAs), such as superior technology and managerial capabilities, which local firms in the host country lack (Driffield and Love, 2007; Narula and Driffield, 2012). When these knowledge sets and skills are transferred to local firms through vertical and horizontal linkages as well as other mechanisms (such as the competition effect), it can positively affect host country economic development by increasing productivity (Giroud, 2007; Jindra et al., 2009).

Potential negative effects of MNE activity have received considerably less attention, from both researchers and policy makers. Negative effects that have received attention include the role of resource seeking MNEs in depleting natural resources (Narula, 2018a; Pearce and Tang, 2019). Other streams of research focus on MNEs being complicit in the exploitation of workers and breaching of human rights (Kolk, 2016). Moreover, there is increasing controversy surrounding the tax avoidance of MNEs and the preferential treatment over local stakeholders they receive from host country policy-makers (Stiglitz, 2019). A small but vocal number of researchers have commented on this "dark-side of MNEstate relations" (Eden and Lenway, 2001, p. 383). However, little attention has been paid to the relationship between MNE activity and inequality and the associated consequences for development. This may in part be due to the overly optimistic view of the effects of FDI (Giuliani and Macchi, 2014), the lack of data about the more vulnerable and deprived population groups and difficulty in modelling distributional effects (Krugman, 2016b).

As Figure 3 shows, there has been a rapid growth in the share of MNE activity in the total economic activity of most countries and a convergence to a higher level of MNE participation in formal economic activity. It is reasonable to conjecture that on average MNEs play a growing role - both directly and indirectly - through the wages they pay and employment they provide (Helpman et al., 2008; Javorcik, 2014). It is therefore no surprise the increasing international activity of MNEs is regarded to play a role in this persistence (and growth) of income inequality (Bourguignon, 2015; Chen et al., 2011; Lee and Wie, 2015; Maskin, 2015; Milanovic, 2016).

Much is still unclear about the mechanisms underlying the link between FDI and inequality. While research in economics has established (and measured) the existence of a wage premium associated with FDI (Hijzen et al., 2013) which results in income inequality between employees of foreign and locally owned firms - there is limited IB research on the topic. We will therefore first give a short overview of how inequality is related to nature of the MNE, before discussing possible research avenues including the moderating role of MNE investment motives and specific elements in the MNE industry, home and host country context we believe most promising.

Our discussion of the link between MNEs and inequality is by no means exhaustive and, as will become clear from our discussion, the factors discussed are interdependent in their mitigating effects. There are (many) other potential mechanisms and other types of inequality and income which can play a role. For instance, MNEs influence public policy such as tax policy in both their home and host countries (Rizopoulos and Sergakis, 2010) which in turn affects income and wealth inequality. MNEs also differ in the dividends they pay their shareholders, and wealth they create for their owners (Kim and Jeon, 2015), thereby affecting other types of income inequality and wealth inequality, in both the home country and their various host countries. Furthermore, reverse relationships exist. For instance, income inequality influences public policy on FDI (Hashai and Buckley, 2019). 
CPOIB

17,1

40

Figure 3.

Inequality and FDI

Indicators 1983-2017

(or closet year)

\begin{tabular}{|c|c|c|c|c|c|c|c|c|}
\hline \multirow{3}{*}{$\begin{array}{r}\text { Country } \\
\text { India }\end{array}$} & \multicolumn{3}{|c|}{ Inequality (Gini) } & \multicolumn{2}{|c|}{ FDI inflow (\% GDP) } & \multicolumn{3}{|c|}{ FDI stock (\% GDP) } \\
\hline & 1983 & 2011 & & 1983 & 2011 & 1983 & 2011 & \\
\hline & 32.1 & 35.7 & 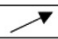 & 0.0 & $\boldsymbol{T}$ & 0.3 & 11.0 & $\pi$ \\
\hline \multirow{2}{*}{ China } & 1990 & 2015 & & 1990 & 2015 & 1990 & 2015 & \\
\hline & 32.3 & 38.6 & $\nabla$ & 0.8 & $\nabla$ & 4.5 & 11.0 & $\nabla$ \\
\hline \multirow{2}{*}{ Indonesia } & 1984 & 2017 & & 1984 & 2017 & 1984 & 2017 & \\
\hline & 32.4 & 38.1 & $\pi$ & 0.2 & 2.0 & 5.3 & 22.8 & $\nabla$ \\
\hline \multirow{2}{*}{ Turkey } & 1987 & 2016 & & 1987 & 2016 & 1987 & 2016 & \\
\hline & 43.5 & 41.9 & - & 0.1 & 1.6 & 7.9 & 17.4 & $\nabla$ \\
\hline \multirow{2}{*}{ Romania } & 1989 & 2015 & & 1989 & 2015 & 1989 & 2015 & \\
\hline & 23.3 & 35.9 & $\pi$ & 0.0 & 7 & 0.0 & 39.4 & $\nabla$ \\
\hline \multirow{2}{*}{ Poland } & 1993 & 2016 & & 1993 & 2016 & 1993 & 2016 & \\
\hline & 26.7 & 30.8 & 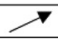 & 1.8 & 3.3 & 2.4 & 40.0 & $\nabla$ \\
\hline \multirow{2}{*}{ Morocco } & 1984 & 2013 & & 1984 & 2013 & 1984 & 2013 & \\
\hline & 39.2 & 39.5 & $\Gamma$ & 0.3 & 3.1 & 16.8 & 48.5 & $\nabla$ \\
\hline \multirow{2}{*}{ Ghana } & 1987 & 2016 & & 1987 & 2016 & 1987 & 2016 & \\
\hline & 35.3 & 43.5 & 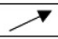 & 0.1 & 6.3 & 2.8 & 54.3 & $\pi$ \\
\hline \multirow{2}{*}{ South Africa } & 1993 & 2014 & & 1993 & 2014 & 1993 & 2014 & \\
\hline & 59.3 & 63.0 & $\nabla$ & 0.0 & 1.6 & 7.9 & 39.6 & 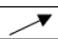 \\
\hline \multirow{2}{*}{ Brazil } & 1981 & 2017 & & 1981 & 2017 & 1981 & 2017 & \\
\hline & 58.0 & 53.3 & 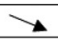 & 1.1 & 3.3 & 8.5 & 30.3 & $\nabla$ \\
\hline \multirow{2}{*}{ Colombia } & 1992 & 2017 & & 1992 & 2017 & 1992 & 2017 & \\
\hline & 51.5 & 49.7 & 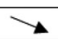 & 1.2 & 4.5 & 6.2 & 58.1 & 7 \\
\hline \multirow{2}{*}{ Jamaica } & 1988 & 2004 & & 1988 & 2004 & 1988 & 2004 & \\
\hline & 43.2 & 45.5 & $\pi$ & -0.3 & 5.9 & 12.7 & 56.3 & $\nabla$ \\
\hline
\end{tabular}

Notes: Within-countries inequality is measured by the Gini coefficient, data derived from the World Bank Database and measured over the first and the latest year available; FDI indicators are derived from the UNCTAD database. All FDI indicators are measured over the same period as the inequality indicator, or the closest year available

A large literature in the intellectual space accorded to economic geography has discussed the spatial distribution effects of FDI at the sub-country, regional level (Barrell and Pain, 1999; Bailey and Driffield, 2002; Kottaridi, 2005; Fu et al., 2011). Most recently, the case of China's rapidly increasing regional income inequalities has been the focus of much research (Fu, 2004; Wei et al., 2009; Zhao and Zhang, 2007). While this is a legitimate and significant area of study, it is a research field in its own right.

Our primary aim in this research note is to introduce an important subject for future research: We are unable, in the space available to us, to provide a comprehensive research agenda on all aspects of the role of the MNE in affecting equality. Nor, it should be emphasised, do we wish to weigh in on the moral and ethical imperatives that shape the actions of MNEs and the net social outcomes of these actions.

\section{Multinational enterprise employment, human capital upgrading and income inequality}

We believe the most direct and strongest link between MNEs and inequality is through the wages they pay and employment they provide, and it provides the most fruitful avenue to start research in the largely unexplored domain of the distributional effects of FDI. The capacity of the MNE to generate employment and upgrade the quality of the host country's human capital is arguably its most immediate and significant contribution to the 
conventional development objectives of an MNE-assisted development agenda. Figure 4 illustrates a general organising framework.

We want to highlight that the direct employment effects of MNEs at an aggregate level tend to be modest. MNEs directly employed only 75.8 million people in 2018 (UNCTAD, 2019), about 2.2 per cent of the global labour force. Nonetheless, MNEs often play a disproportionately large role in two very different types of sectors. First, they tend to have a disproportionately large role in the more competitive or dynamic sectors typified by high growth rates. Second, MNEs tend to dominate in mature sectors where economies of scale, branding and advertising enterprises and within-country inequality determine market share (e.g. petroleum products, chemicals, automobiles, food and beverages and consumer goods). In such sectors, while the technology underlying these industries may be diffused and codified, proprietary FSAs have meant that just a few MNEs maintain a large share of the global market. The significance of MNEs is much greater when one includes secondary and tertiary employment effects, as illustrated in Figure 4.

\section{Knowledge spill-overs through employee mobility}

One of the key sources of differences between MNEs and local firms is FSAs. They explain why MNEs pay better than locally owned firms (Almeida, 2007; Chen et al., 2011; Heyman et al., 2007; Hijzen et al., 2013) creating direct distributional effects instantly. This is because these higher wages are considered to reflect a desire to prevent spill-overs through attrition to domestic competitors. Through training and experience, MNEs' local employees become familiar with the firm-specific technology and management practices (Martin and Salomon, 2003) which are superior to those of local firms (Caves, 1996; Dunning, 1988; Javorcik, 2014; Javorcik and Poelhekke, 2017; Rugman and Verbeke, 2001). When employees find jobs elsewhere or start their own companies, knowledge leaks out of the firm and the MNE may lose its competitive edge. The relatively high wages paid by MNEs are thus primarily motivated by the need to retain employees (Fosfuri et al., 2001; Glass and Saggi, 1999, 2002;

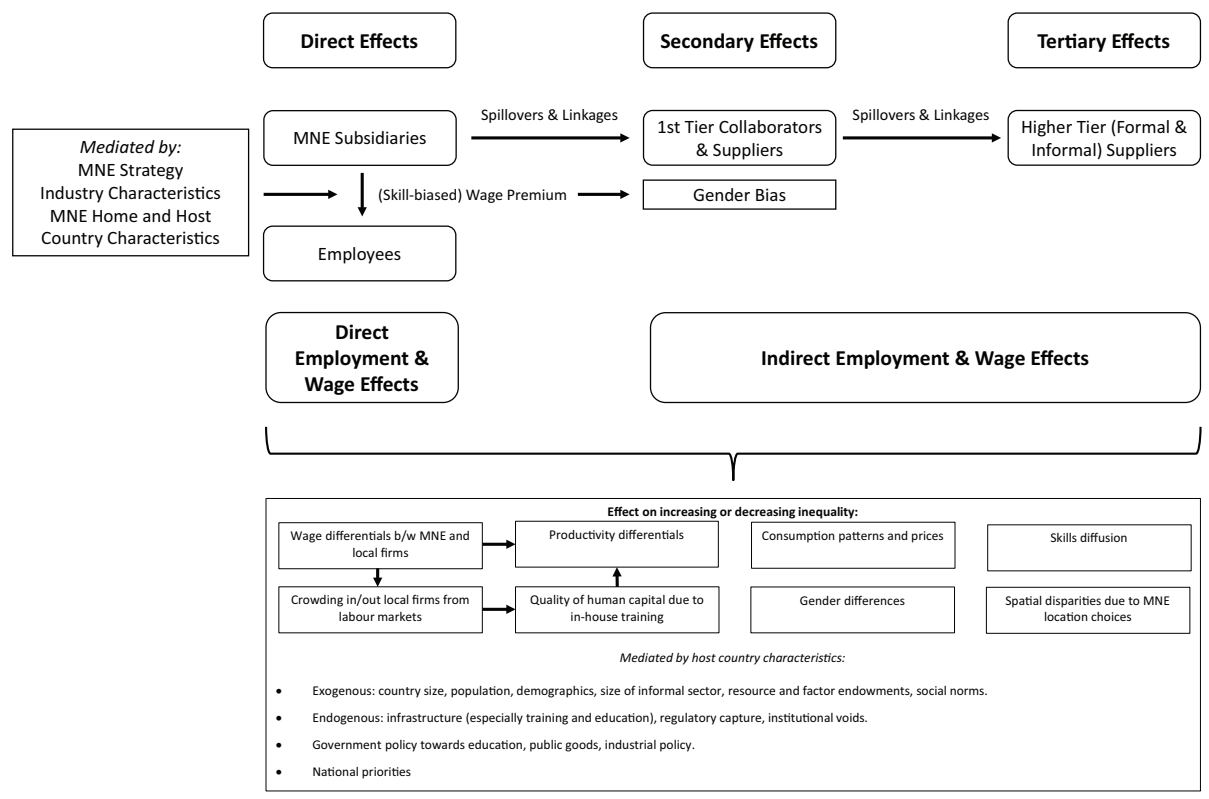

Figure 4 . Organising framework 
CPOIB 17,1

Globerman et al., 1994). While these relatively high paying jobs are obviously beneficial to the employees securing them, they do cause a divergence in incomes.

\section{Skill-biased employment}

MNEs require a large spectrum of both high-skilled employees and unskilled workers. At the upper end of the spectrum, highly skilled technical and managerial expertise is required to fully exploit the MNE's FSAs. FSAs are embodied in managerial practises, products and process designs, and services provision which have typically been transferred from the MNE headquarters to subsidiaries. Managerial and technical roles in an MNE's subsidiary are reliant on greater skills than local firms because of the complex context of multinationality and (cultural) distances between the headquarters and subsidiaries, as well as multiple interests across geographies (Collings et al., 2019; Fajnzylber and Fernandes, 2009; Meyer and Xin, 2018; Morris et al., 2016; Tarique et al., 2006; Tatoglu et al., 2016). MNEs typically rely on skilled employees to have a high threshold level of absorptive capacity (Wang and Blomström, 1992). Consequently, skilled workers in MNEs therefore benefit more in terms of increased productivity and associated wages compared to unskilled workers (Narula, 2019).

At the other end of the spectrum, MNEs also locate abroad for the exploitation of lowwage unskilled labour, and indeed, this may be the host country's primary location advantage. The skills required tend to be low by definition. Still, this skill level is likely to be higher relative to that of the average domestic firm in the host country (Fajnzylber and Fernandes, 2009; Feenstra and Hanson, 1996; Keller, 2004). Moreover, while much efficiency seeking FDI may indeed create low skilled, assembly (line) jobs in the 20th century, the growing volumes and increasing automatisation and complexity of the processes and products involved have increased considerably over the past decade. Since the 2008 crises FDI has de-industrialized and efficiency seeking FDI now includes a considerable share of (administrative) service jobs. Consequently, the skills demanded by efficiency-seeking-FDIinduced employment has increased (Francisco, 2015; Lee and Wie, 2015) and its positive effects for the least advantaged have dwindled.

Previous studies (Beugelsdijk et al., 2008) have distinguished between the effects of vertical and horizontal FDI. Horizontal FDI may create larger spill-over effects than vertical FDI because of its more intensive use of (knowledge) capital in the local economy. Vertical FDI, on the other hand, is associated with a relatively stronger impact on local labour demand. Consequently, the relative importance of these two effects will determine which type of FDI affects economic growth to the largest extent.

These increasing skill demands have a detrimental effect on female employment and, consequently, on gender inequality in employment. Initially, efficiency-seeking FDI in Asia, Africa and Mexico created female employment, as women were the cheapest and most productive source of low skilled labour (Francisco, 2015). Female wages are traditionally lower, as they are culturally perceived as secondary earners, not breadwinners, and a gender wage gap is socially accepted (Akerlof and Yellen, 1990; Charles, 2011). The gender wage gap, limited labour rights and poor access to job training for women further enforces this gender wage gap (Seguino, 2011; Doraisami, 2012; Berik, 2012). Over the past decade, however, the demand for low-wage, unskilled female workers has plummeted, concomitant with the increase of skill-bias embodied in FDI. As women in developing countries tend on average to be less educated and trained than men, there are fewer opportunities for female workers. The share of female employment has consequently dropped in many countries, the so-called "defeminisation" of FDI (Aguayo-Tellez, 2011; Francisco, 2015). 
Empirically, Hyun and Ravi (2019) and Ravi (2018) find that trade and FDI liberalisation in India has indeed largely benefited relatively high-skilled workers. Their analysis reveals an additional factor in the relationship between MNEs and inequality: the informal sector. Because of the skill-bias in MNEs and their supplier (and the absence of hard regulation), low-skilled workers are often employed informally. Informal employment is characterised by low productivity, a lack of social security and legal protection, as well as insubstantial and ad-hoc income (Narula, 2019).

Despite low-skilled workers not being employed (and employable) by MNEs, MNEs have

Multinational enterprises and within-country inequality an impact on workers in the informal sector too. MNEs are under pressure (from their home country and markets) to ensure relatively high standards of product quality and working conditions in their supply chains. They therefore have strict labour standards guidelines for their suppliers (Davies and Vadlamannati, 2013; Ravi, 2018; Schrempf-Stirling and Palazzo, 2016). Historically, a network of informal enterprises provided inputs for many of the firsttier MNE suppliers in developing countries. As MNE requirements for suppliers have tightened and are expanded to second and third-tier suppliers, many informal enterprises lose their business, as they are unregistered and commonly lack the resources, skills and access to credit to meet MNE requirements (Godfrey, 2011; Kabeer, 2004; Narula, 2019). The resulting shrinking size of the informal sector is detrimental for its wages and employment (Ravi, 2018), a concerning development as those working in the informal sector are the most vulnerable part of the population with little access to high quality nutrition and health care (Banerjee and Duflo, 2007; La Porta and Shleifer, 2008).

\section{Avenues for further research}

While the macro-level research since the 1980s has given us many insights into the link between FDI and development, it tells us very little about how FDI affects inequality within countries. While a robust literature exists on understanding the nature and magnitude of these inequalities per se, we know very little on the role of MNEs. By focussing on MNEs, key actors in an age of globalisation, we offer a few suggestions for future research where IB can be particularly useful.

\section{How do multinational enterprise investment motivations affect inequality?}

It is well-known that investment motives play a significant role in shaping the distributional effects of FDI (Morrissey, 2012; Santangelo, 2018). For instance, as Pearce and Tang (2019) note, market-seeking FDI improves the product offerings for consumers, and increased competition can further lower prices. Although lower prices may not directly affect income, it does affect welfare. At the same time, market-seeking FDI can also crowd out local firms and negatively affect employment (Kosova, 2010; Narula and Dunning, 2010). Natural resource seeking FDI on the other hand, often results in fewer linkages with developing host economies (Narula, 2018a) than knowledge- and efficiency-seeking FDI. The investment motive of the MNE therefore can thereby have a substantial moderating effect on inequality. However, it is simplistic to consider specific FDI motives to be associated with specific net outcomes, because this is a function of the complementarity between the MNE's motivation to make the investment in the first place, and the host country's location advantages.

\section{How is inequality different for FDI in the service sector?}

While historically much FDI was concentrated in the primary and manufacturing sectors, with the establishment of the WTO and the growing liberalisation of the global economy, there has been a growing role of MNEs in the provision of cross-border services (including 
CPOIB 17,1

banking, insurance, hospitality, real estate, and entertainment). We know little about the development effects of services FDI, and consequently the net distributional effects of services MNEs. One such effect may be an increase in demand for "pink-collar" jobs which include unskilled employment in the service industry (Francisco, 2015), including (for instance) cleaning ladies in international hotels chains. While FDI in the service industry may provide employment to unskilled women, the quality of these jobs can even be inferior to that in local firms (Oxfam, 2017). The traditional belief that FDI provides relatively attractive and well-paying jobs, stemming from the days where MNEs operated "miniature replicas" in developing countries that covered all aspects of value adding activity, is in need of revaluation given the more recent trends in FDI.

\section{What is the role of spatial disparities in location advantages on inequalities?}

MNEs tend to concentrate in urban areas, as there is superior infrastructure and skilled employees available compared to (remote) rural areas. Moreover, in several countries, urban areas are designated by governments as special economic zones with preferential taxes and regulations. Consequently, FDI-induced high-quality employment tends to concentrate in urban areas (Yabuuchi, 1999). This amplifies inequalities rooted in low levels of infrastructure and the absence of employment opportunities in rural areas. Even within urban areas there can be great diversity in the quality of infrastructure. For instance, access to quality education, health care and public transportation to the employment hubs where MNEs are typically concentrated is limited from many urban slums. Moreover, for residents of these disadvantaged areas, social stigma and lack of advantageous social networks may reinforce inequalities (Le Galès and Pierson, 2019).

\section{How can multinational enterprises affect the informal sector?}

Up to 80 per cent of less-developed economies tend to be engaged in the informal sector, and despite its size and economic relevance, IB research and the role of FDI-assisted development on the informal sector is poorly studied (Narula 2018a, 2019). Ravi's (2018) small scale investigation into this relationship demonstrates the effects may be profound. Many informal enterprises historically depend on ties with formal firms, and these ties may be severed due to the growing compliance requirements MNEs place on suppliers in their supply chains (Narula, 2019). More insight and awareness are needed on how the actions of MNEs, sometimes even when intended to improve labour conditions, can negatively affect the most vulnerable members of society at the lowest percentiles of the income distribution.

Informal sectors are poorly understood, but we do know they are intransigent to radical change. Given that informality is a key hallmark of many developing countries, and at the heart of underdevelopment, any "real" progress in development terms requires understanding how MNEs can best engage with informal actors.

\section{How do home countries influence the activities of their multinational enterprises?}

Incidents in the global value chains of MNEs and the consequently increased media scrutiny has resulted in substantial pressure from home country consumers, governments and NGO on MNEs to ensure fair wages and working conditions at their subsidiaries and suppliers (Davies and Vadlamannati, 2013; Detomasi, 2008; Ravi, 2018; Schrempf-Stirling and Palazzo, 2016; Toffel et al., 2015). Meanwhile, other research has found that home country consumers are not sensitive to the ethical considerations in their purchasing decisions (Auger and Devinney, 2007; Öberseder et al., 2011) and high levels institutional pressure to improve labour conditions in MNE home countries prompts MNEs to relocate their socially 
undesirable operations abroad (Surroca et al., 2013; Weng and Peng, 2018). While IB literature has come a long way in establishing the relevance of the home country context for MNEs (Cuervo-Cazurra et al., 2015; Hoskisson et al., 2013; McGaughey et al., 2016), there is room for improvement in our understanding of how the MNE home country context affects distributional outcomes in MNE host countries.

Multinational enterprises and within-country inequality

\section{Conclusions}

Research into the extent to which MNEs affect within-country inequalities is still in its infancy. We are only beginning to understand the complexities of how multinationals affect inequality in their host countries. Like Oetzel and Doh (2009), we find initial research on the impact of FDI and MNEs on host countries to excessively rely on spill-over arguments and present an overly rosy view of net outcomes for host countries. We think Pearce and Tang's (2019) suggestion to explore the interaction between MNEs and national economies from this angle can generate important new insights. In our view, these insights should be complemented by studies on how MNEs affect the development of host countries in other dimensions beyond income and employment.

While a number of SDGs have been extensively studied in IB research (particularly clean energy, climate action and innovation), little to no attention has been paid to those SDGs that affect the people at the bottom of the income distribution most directly: poverty, hunger, health and education (Kourula et al., 2017). As reduced inequality is a precondition for advancing the development agenda on these SDGs, and inequality is affected by MNE activity, research on these SDGs in particular could further advance our understanding of the broader impact MNEs have on development.

MNEs seek specific location advantages, and by definition, the kinds of workers they employ reflect the comparative advantage of the host location. Private firms, including MNEs and their domestic suppliers, are focused on financial objectives, only secondarily pursuing social objectives (Kannothra et al., 2018). While they may have CSR objectives which include increasing diversity and improving the welfare of their workers, the efficiency of their investments and the economic returns are often paramount. Besides, every action no matter how well intended - will likely have unintended consequences, some of which may be adverse. It can be argued that it is a fool's errand to predict (and minimise) adverse outcomes, especially those that are several degrees removed from the MNE. It also seems unrealistic to hold the MNE responsible for those outcomes that only become apparent several years down the line, or are several degrees removed. Nonetheless, MNEs are increasingly conscious of the public and stakeholder awareness of social outcomes, and future research that helps to minimise outcomes that are undesirable becomes necessary if academic research is to offer concrete policy and firm implications. We have offered a few suggestions for future research on the relationship between MNEs and inequality, particularly at the firm, industry and country level.

It is important to note that we do not take the view that the MNE seeks deliberately to negatively affect inequality. Rather, we believe that MNEs (like most firms) are primarily rent-optimising economic actors, whose central responsibility is to its stakeholders. Their influence on inequality is largely passive, and (from the MNE's perspective) an unintended outcome from their primary value-adding activities. Nonetheless, the consequences of MNEs on inequality - whether intended or unfortunate - are real, and deserve more careful study if states, civil society or firms are to act to mitigate them. 
CPOIB

17,1

\section{Notes}

1. See Pineli et al. (2019) for an overview.

2. Exceptions include but are not limited to Dunning (2006), Giuliani and Macchi (2014), Kolk (2010), and economic work from Amin (1977), Evans (1979), Kohler and Tausch (2002).

3. Unlike Marx's approach to capital, Piketty includes all sources of wealth regardless of the way in which it was acquired.

\section{References}

Aguayo-Tellez, E. (2011), "The impact of trade liberalization policies and FDI on gender inequalities", background paper, 15 April, World Bank, Washington, DC.

Akerlof, G.A. and Yellen, J.L. (1990), "The fair wage-effort hypothesis and unemployment", The Quarterly Journal of Economics, Vol. 105 No. 2, pp. 255-283.

Almeida, R. (2007), "The labor market effects of foreign owned firms", Journal of International Economics, Vol. 72 No. 1, pp. 75-96.

Altomonte, C. and Pennings, E. (2009), "Domestic plant productivity and incremental spillovers from foreign direct investment", Journal of International Business Studies, Vol. 40 No. 7, pp. 1131-1148.

Alvaredo, F., Chancel, L., Piketty, T., Saez, E. and Zucman, G. (2017), 2018 World Inequality Report, World Inequality Lab, Paris.

Amin, S. (1977), Imperialism and Unequal Development, Monthly Review Press, New York, NY.

Auger, P. and Devinney, T.M. (2007), "Do what consumers say matter? The misalignment of preferences with unconstrained ethical intentions", Journal of Business Ethics, Vol. 76 No. 4, pp. 361-383.

Bailey, D. and Driffield, N. (2002), "Hymer and uneven development revisited: foreign direct investment and regional inequalities", Contributions to Political Economy, Vol. 21 No. 1, pp. 55-68.

Banerjee, A.V. and Duflo, E. (2007), "The economic lives of the poor", Journal of Economic Perspectives, Vol. 21 No. 1, pp. 141-168.

Barrell, R. and Pain, N. (1999), "European growth and integration: domestic institutions, agglomerations and foreign direct investment in Europe", European Economic Review, Vol. 43 Nos 4/6, pp. 925-935.

Benito, G.R. and Narula, R. (2007), "States and firms on the periphery: the challenges of a globalizing world", in Benito, G.R. and Narula, R. (Eds), Multinationals on the Periphery, Palgrave Macmillan, London.

Berik, G. (2012), "Growth with gender inequity: Another look at East Asian development”, in Berik, G., Van der Meulen Rodgers, Y. and Zammit, A. (Eds), Social Justice and Gender Equality: Rethinking Development Strategies and Macroeconomic Policies, Routledge, New York, NY.

Beugelsdijk, S., Smeets, R. and Zwinkels, R. (2008), "The impact of horizontal and vertical FDI on host's country economic growth", International Business Review, Vol. 17 No. 4, pp. 452-472.

Boucoyannis, D. (2013), "The equalizing hand: why Adam Smith thought the market should produce wealth without steep inequality", Perspectives on Politics, Vol. 11 No. 4, pp. 1051-1070.

Bourguignon, F. (2015), The Globalization of Inequality, Princeton University Press, Princeton, NJ.

Buckley, P.J., Clegg, J. and Wang, C. (2007), "Is the relationship between inward FDI and spillover effects linear? An empirical examination of the case of China", Journal of International Business Studies, Vol. 38 No. 3, pp. 447-459.

Caves, R.E. (1996), Multinational Enterprise and Economic Analysis, Cambridge University Press, Cambridge. 
Charles, A. (2011), "Fairness and wages in Mexico's maquiladora industry: an empirical analysis of labor demand and the gender wage gap", Review of Social Economy, Vol. 69 No. 1, pp. 1-28.

Chen, M.A. (2012), "The informal economy: definitions, theories and policies”, WIEGO working Paper, Vol. 1 No. 26, pp. 90141-901414.

Chen, Z., Ge, Y. and Lai, H. (2011), "Foreign direct investment and wage inequality: evidence from China", World Development, Vol. 39 No. 8, pp. 1322-1332.

Cheung, H.Y. and Chan, A.W. (2007), "How culture affects female inequality across countries: an empirical study", Journal of Studies in International Education, Vol. 11 No. 2, pp. 157-179.

Collings, D.G., Mellahi, K. and Cascio, W.F. (2019), "Global talent management and performance in multinational enterprises: a multilevel perspective”, Journal of Management, Vol. 45 No. 2, pp. 540-566.

Cuervo-Cazurra, A., Meyer, K. and Ramamurti, R. (2015), "Explaining the internationalization of emerging-economy multinationals: the relative resource specialization of firm and environment", in Demirbag M. and Yaprak A. (Eds), Handbook of Emerging Market Multinationals, Edgar Elgar, Northampton, MA, pp. 68-88.

Davies, R.B. and Vadlamannati, K.C. (2013), "A race to the bottom in labor standards? An empirical investigation", Journal of Development Economics, Vol. 103, pp. 1-14.

Detomasi, D.A. (2008), "The political roots of corporate social responsibility", Journal of Business Ethics, Vol. 82 No. 4, pp. 807-819.

Doraisami, A. (2012), "The gender implications of macroeconomic policy and performance in Malaysia", in Berik, G., Van der Meulen Rodgers, Y. and Zammit, A. (Eds), Social Justice and Gender Equality: Rethinking Development Strategies and Macroeconomic Policies, Routledge, New York, NY.

Driffield, N. and Love, J.H. (2007), "Linking FDI motivation and host economy productivity effects: conceptual and empirical analysis", Journal of International Business Studies, Vol. 38 No. 3, pp. 460-473.

Dunning, J. (1958), American Investment in British Manufacturing Industry, George Allen and Unwin, London.

Dunning, J.H. (1981), "Explaining the international direct investment position of countries: towards a dynamic or developmental approach", Weltwirtschaftliches Archiv, Vol. 117 No. 1, pp. 30-64.

Dunning, J.H. (1988), "The eclectic paradigm of international production: a restatement and some possible extensions", Journal of International Business Studies, Vol. 19 No. 1, pp. 1-31.

Dunning, J.H. (2006), “Towards a new paradigm of development: Implications for the determinants of international business", Transnational Corporations, Vol. 15 No. 1, pp. 173-227.

Eden, L. and Lenway, S. (2001), "Introduction to the symposium multinationals: the Janus face of globalization", Journal of International Business Studies, Vol. 32 No. 3, pp. 383-400.

Evans, P.B. (1979), Dependent Development: The Alliance of Multinational, State, and Local Capital in Brazil, Princeton University Press, Princeton, NJ.

Fajnzylber, P. and Fernandes, A.M. (2009), "International economic activities and skilled labour demand: evidence from Brazil and China”, Applied Economics, Vol. 41 No. 5, pp. 563-577.

Feenstra, R.C. and Hanson, G.H. (1996), "Globalization, outsourcing, and wage inequality", American Economic Review, Vol. 86 No. 2, pp. 240-245.

Fosfuri, A., Motta, M. and Rønde, T. (2001), "Foreign direct investment and spillovers through workers' mobility", Journal of International Economics, Vol. 53 No. 1, pp. 205-222.

Francisco, J. (2015), "Markets, globalization, and gender", in Benería, L., Berik, G. and Floro, M. (Eds), Gender, Development and Globalization: Economics as If All People Mattered, Routledge, New York, NY. 
CPOIB 17,1

$\mathrm{Fu}, \mathrm{X}$. (2004), "Limited linkages from growth engines and regional disparities in China”, Journal of Comparative Economics, Vol. 32 No. 1, pp. 148-164.

Fu, X., Pietrobelli, C. and Soete, L. (2011), "The role of foreign technology and indigenous innovation in the emerging economies: technological change and catching-up", World Development, Vol. 39 No. 7, pp. 1204-1212.

Giroud, A. (2007), "MNEs vertical linkages: the experience of Vietnam after Malaysia", International Business Review, Vol. 16 No. 2, pp. 159-176.

Giuliani, E. and Macchi, C. (2014), "Multinational corporations' economic and human rights impacts on developing countries: a review and research agenda", Cambridge Journal of Economics, Vol. 38 No. 2, pp. 479-517.

Glass, A.J. and Saggi, K. (1999), "FDI policies under shared factor markets", Journal of International Economics, Vol. 49 No. 2, pp. 309-332.

Glass, A.J. and Saggi, K. (2002), "Multinational firms and technology transfer", Scandinavian Journal of Economics, Vol. 104 No. 4, pp. 495-513.

Globerman, S., Ries, J.C. and Vertinsky, I. (1994), "The economic performance of foreign affiliates in Canada", The Canadian Journal of Economics, Vol. 27 No. 1, pp. 143-156.

Godfrey, P.C. (2011), "Toward a theory of the informal economy", Academy of Management Annals, Vol. 5 No. 1, pp. 231-277.

Gradín, C. and Sen, S. (2019), "Measuring inequality in middle-income countries", working paper, 13 May, United Nations, New York, NY.

Gustavsson, M. and Jordahl, H. (2008), "Inequality and trust in Sweden: some inequalities are more harmful than others", Journal of Public Economics, Vol. 92 Nos 1/2, pp. 348-365.

Ha, Y.J. and Giroud, A. (2015), "Competence-creating subsidiaries and FDI technology spillovers", International Business Review, Vol. 24 No. 4, pp. 605-614.

Hashai, N. and Buckley, P. (2019), "Within country inequality and globalization", paper presented at Academy of International Business (AIB) Annual Meeting, Copenhagen, 24-27 June.

Helpman, E., Itskhoki, O. and Redding, S. (2008), "Wages, unemployment and inequality with heterogeneous firms and workers”, working paper (No. w14122), National Bureau of Economic Research, Cambridge, MA.

Heyman, F., Sjöholm, F. and Tingvall, P.G. (2007), "Is there really a foreign ownership wage premium? Evidence from matched employer-employee data", Journal of International Economics, Vol. 73 No. 2, pp. 355-376.

Hijzen, A., Martins, P.S., Schank, T. and Upward, R. (2013), "Foreign-owned firms around the world: a comparative analysis of wages and employment at the micro-level", European Economic Review, Vol. 60 No. C, pp. 170-188.

Hoskisson, R.E., Wright, M., Filatotchev, I. and Peng, M.W. (2013), "Emerging multinationals from midrange economies: the influence of institutions and factor markets", Journal of Management Studies, Vol. 50 No. 7, pp. 1295-1321.

Hughes, C. (2018), Fair Shot: Rethinking Inequality and How we Earn, St. Martin's Press, New York, NY.

Hymer, S. (1975), "The multinational corporation and the law of uneven development", in Radice, H. (Ed.), International Firms and Modern Imperialism, Penguin, Handsworth, pp. 37-62.

Hyun, Y. and Ravi, S. (2019), "Essays on place-based development policies: Evidence from special economic zones in India”, working paper, unpublished.

Javorcik, B. (2014), "Does FDI bring good jobs to host countries?", The World Bank Research Observer, Vol. 30 No. 1, pp. 74-94.

Javorcik, B. and Poelhekke, S. (2017), "Former foreign affiliates: cast out and outperformed?", Journal of the European Economic Association, Vol. 15 No. 3, pp. 501-539. 
Jindra, B., Giroud, A. and Scott-Kennel, J. (2009), "Subsidiary roles, vertical linkages and economic development: lessons from transition economies", Journal of World Business, Vol. 44 No. 2, pp. 167-179.

Kabeer, N. (2004), “Globalisation, labour standards and women's rights: dilemmas of collective (in) action in an interdependent world", Feminist Economics, Vol. 10 No. 1, pp. 3-35.

Kannothra, C.G., Manning, S. and Haigh, N. (2018), "How hybrids manage growth and social-business tensions in global supply chains: the case of impact sourcing", Journal of Business Ethics, Vol. 148 No. 2, pp. 271-290.

Kaplinsky, R. (2013), Globalization, Poverty and Inequality: Between a Rock and a Hard Place, John Wiley and Sons, Hoboken, NJ.

Keller, W. (2004), "International technology diffusion”, Journal of Economic Literature, Vol. 42 No. 3, pp. $752-782$.

Kim, J. and Jeon, Y. (2015), "Dividend policy and corporate social responsibility: a comparative analysis of multinational enterprise subsidiaries and domestic firms in Korea", Emerging Markets Finance and Trade, Vol. 51 No. 2, pp. 306-319.

Kobrin, S.J. (2017), "Bricks and mortar in a borderless world: globalization, the backlash, and the multinational enterprise", Global Strategy Journal, Vol. 7 No. 2, pp. 159-171.

Kohler, G. and Tausch, A. (2002), Global Keynesianism: Unequal Exchange and Global Exploitation, Nova Publishers, Huntington, New York, NY.

Kolk, A. (2010), "Social and sustainability dimensions of regionalization and (semi) globalization", Multinational Business Review, Vol. 18 No. 1, pp. 51-72.

Kolk, A. (2016), "The social responsibility of international business: from ethics and the environment to CSR and sustainable development", Journal of World Business, Vol. 51 No. 1, pp. 23-34.

Kosova, R. (2010), "Do foreign firms crowd out domestic firms? Evidence from the Czech Republic", The Review of Economics and Statistics, Vol. 92 No. 4, pp. 861-881.

Kottaridi, C. (2005), “The 'core-periphery' pattern of FDI-led growth and production structure”, Applied Economics, Vol. 37 No. 1, pp. 99-113.

Kourula, A., Pisani, N. and Kolk, A. (2017), "Corporate sustainability and inclusive development: highlights from international business and management research", Current Opinion in Environmental Sustainability, Vol. 24, pp. 14-18.

Krugman, P. (2007), The Conscience of a Liberal, WW Norton and Company, New York, NY.

Krugman, P. (2016a), "Is vast inequality necessary?”, The New York Times, 15 January.

Krugman, P. (2016b), "Economists and inequality”, The New York Times, 8 January.

La Porta, R. and Shleifer, A. (2008), "The unofficial economy and economic development (no. w14520)", National Bureau of Economic Research, Cambridge, MA, December.

Lall, S. and Streeten, P. (1977), Foreign Investment, Transnationals and Developing Countries, Palgrave Macmillan, London.

Le Galès, P. and Pierson, P. (2019), "Superstar cities and the generation of durable inequality", Daedalus, Vol. 148 No. 3, pp. 46-72.

Lee, J.W. and Wie, D. (2015), “Technological change, skill demand, and wage inequality: evidence from Indonesia”, World Development, Vol. 67, pp. 238-250.

Lewis, W.A. (1954), "Economic development with unlimited supplies of labour", The Manchester School, Vol. 22 No. 2, pp. 139-191.

McGaughey, S.L., Kumaraswamy, A. and Liesch, P.W. (2016), "Institutions, entrepreneurship and co-evolution in international business", Journal of World Business, Vol. 51 No. 6, pp. 871-881. 
CPOIB 17,1

Marshall, A. (1919), Industry and Trade; a Study of Industrial Technique and Business Organization, and of Their Influences on the Conditions of Various Classes and Nations, Macmillan, London.

Martin, X. and Salomon, R. (2003), "Knowledge transfer capacity and its implications for the theory of the multinational corporation”, Journal of International Business Studies, Vol. 34 No. 4, pp. 356-373.

Marx, K. (1867), Capital: A Critique of Political Economy (Volume One), Otto Meissners Verlag, Hamburg.

Maskin, E. (2015), "Why haven’t global markets reduced inequality in emerging economies?”, The World Bank Economic Review, Vol. 29 No. 1, pp. S48-S52.

Meyer, K.E. and Sinani, E. (2009), "When and where does foreign direct investment generate positive spillovers? A meta-analysis", Journal of International Business Studies, Vol. 40 No. 7, pp. 1075-1094.

Meyer, K.E. and Xin, K.R. (2018), "Managing talent in emerging economy multinationals: integrating strategic management and human resource management", The International Journal of Human Resource Management, Vol. 29 No. 11, pp. 1827-1855.

Milanovic, B. (2016), Global Inequality: A New Approach for the Age of Globalization, Harvard University Press, Cambridge, MA.

Morris, S., Snell, S. and Björkman, I. (2016), "An architectural framework for global talent management”, Journal of International Business Studies, Vol. 47 No. 6, pp.723-747.

Morrissey, O. (2012), "FDI in sub-Saharan Africa: few linkages, fewer spillovers", The European Journal of Development Research, Vol. 24 No. 1, pp. 26-31.

Narula, R. (1996), Multinational Investment and Economic Structure: Globalisation and Competitiveness, Routledge, London.

Narula, R. (2003), Technology and Globalisation: Interdependence, Innovation Systems and Industrial Policy, Polity Press, Cambridge.

Narula, R. (2018a), "Multinational firms and the extractive sectors in the 21st century: can they drive development?", Journal of World Business, Vol. 53 No. 1, pp. 85-91.

Narula, R. (2018b), “An extended dual economy model: implications for emerging economies and their multinational firms", International Journal of Emerging Markets, Vol. 13 No. 3, pp. 586-602.

Narula, R. (2019), "Enforcing higher labour standards within developing country value chains: consequences for MNEs and informal actors in a dual economy", Journal of International Business Studies, Vol. 50 No. 9, available at: https://doi.org/10.1057/s41267-019-00265-1

Narula, R. and Driffield, N. (2012), "Does FDI cause development? The ambiguity of the evidence and why it matters", The European Journal of Development Research, Vol. 24 No. 1, pp. 1-7.

Narula, R. and Dunning, J.H. (2000), "Industrial development, globalization and multinational enterprises: new realities for developing countries", Oxford Development Studies, Vol. 28 No. 2, pp. 141-167.

Narula, R. and Dunning, J.H. (2010), "Multinational enterprises, development and globalization: some clarifications and a research agenda", Oxford Development Studies, Vol. 38 No. 3, pp. 263-287.

Narula, R. and Pineli, A. (2019), "Improving the developmental impact of multinational enterprises: policy and research challenges", Journal of Industrial and Business Economics, Vol. 46 No. 1, pp. 1-24.

Nolan, N., Salverda, W., Checchi, D., Marx, I., McKnight, A., György Tóth, I., Van de. and Werfhorst, H. (Eds), (2014)Changing Inequalities and Societal Impacts in Rich Countries: Thirty Countries' Experiences, Oxford University Press, Oxford.

Öberseder, M., Schlegelmilch, B.B. and Gruber, V. (2011), "Why don't consumers care about CSR? A qualitative study exploring the role of CSR in consumption decisions", Journal of Business Ethics, Vol. 104 No. 4, pp. 449-460. 
Oetzel, J. and Doh, J.P. (2009), “MNEs and development: a review and reconceptualization”, Journal of World Business, Vol. 44 No. 2, pp. 108-120.

Oxfam (2017), Tourism's Dirty Secret: The Exploitation of Hotel Housekeepers, Oxfam, Ottawa.

Pearce, R. and Tang, Y. (2019), "Evaluation of the performance and implications of multinationals: a framework of issues", Critical Perspectives on International Business, Vol. 1.

Multinational enterprises and within-country inequality

Pietrobelli, C. and Rabellotti, R. (2011), "Global value chains meet innovation systems: are there learning opportunities for developing countries?", World Development, Vol. 39 No. 7, pp. 1261-1269.

Piketty, T. (2013), Capital in the Twenty-First Century, Harvard University Press, Cambridge, MA.

Pineli, A., Narula, R. and Belderbos, R. (2019), "FDI, multinationals and structural change in developing countries", working paper, United Nations University-Maastricht Economic and Social Research Institute on Innovation and Technology (MERIT), Maastricht.

Ravi, S. (2018), "Understanding the effect of Indian special economic zones on the informal economy", working paper, unpublished.

Rizopoulos, Y.A. and Sergakis, D.E. (2010), "MNEs and policy networks: institutional embeddedness and strategic choice", Journal of World Business, Vol. 45 No. 3, pp. 250-256.

Rugman, A.M. and Verbeke, A. (2001), "Subsidiary-specific advantages in multinational enterprises", Strategic Management Journal, Vol. 22 No. 3, pp. 237-250.

Santangelo, G.D. (2018), "The impact of FDI in land in agriculture in developing countries on host country food security", Journal of World Business, Vol. 53 No. 1, pp. 75-84.

Schrempf-Stirling, J. and Palazzo, G. (2016), "Upstream corporate social responsibility: the evolution from contract responsibility to full producer responsibility", Business and Society, Vol. 55 No. 4, pp. 491-527.

Seguino, S. (2011), "Help or hindrance? Religion's impact on gender inequality in attitudes and outcomes", World Development, Vol. 39 No. 8, pp. 1308-1321.

Sen, A.K. (1992), Inequality Reexamined, Harvard University Press, Cambridge, MA.

Sen, A.K. (2009), The Idea of Justice, Harvard University Press, Cambridge, MA.

Smith, A. (1776), An Inquiry into the Nature and Causes of the Wealth of Nations, W. Strahan and T. Cadell, London.

Stiglitz, J.E. (2012), The Price of Inequality: How Today's Divided Society Endangers Our Future, WW Norton and Company, New York, NY.

Stiglitz, J.E. (2019), "How can We tax footloose multinationals?”, Project Syndicate, 13 February.

Surroca, J., Tribó, J.A. and Zahra, S.A. (2013), "Stakeholder pressure on MNEs and the transfer of socially irresponsible practices to subsidiaries", Academy of Management Journal, Vol. 56 No. 2, pp. 549-572.

Tarique, I., Schuler, R. and Gong, Y. (2006), "A model of multinational enterprise subsidiary staffing composition", The International Journal of Human Resource Management, Vol. 17 No. 2, pp. 207-224.

Tatoglu, E., Glaister, A.J. and Demirbag, M. (2016), "Talent management motives and practices in an emerging market: a comparison between MNEs and local firms", Journal of World Business, Vol. 51 No. 2, pp. 278-293.

Toffel, M.W., Short, J.L. and Ouellet, M. (2015), "Codes in context: how states, markets, and civil society shape adherence to global labor standards", Regulation and Governance, Vol. 9 No. 3, pp. 205-223.

Ünal, A.F. and Chen, C. (2017), "Inequality beliefs and ethical tradeoffs: a cross-cultural investigation", Academy of Management Proceedings, Vol. 2017 No. 1, p. 16242.

UNCTAD (2019), World Investment Report 2019, United Nations, New York, NY.

United Nations (2019), Human Development Report 2019, United Nations, New York, NY.

Uslaner, E.M. and Brown, M. (2005), "Inequality, trust, and civic engagement", American Politics Research, Vol. 33 No. 6, pp. 868-894. 
CPOIB 17,1

Wang, J.Y. and Blomström, M. (1992), "Foreign investment and technology transfer: a simple model”, European Economic Review, Vol. 36 No. 1, pp. 137-155.

Wei, K., Yao, S. and Liu, A. (2009), "Foreign direct investment and regional inequality in China”, Review of Development Economics, Vol. 13 No. 4, pp. 778-791.

Weng, D.H. and Peng, M.W. (2018), "Home bitter home: how labor protection influences firm offshoring", Journal of World Business, Vol. 53 No. 5, pp. 632-640.

Wilkinson, R.G. (1999), "Income inequality, social cohesion, and health: clarifying the theory - a reply to muntaner and lynch", International Journal of Health Services, Vol. 29 No. 3, pp. 525-543.

Wilkinson, R.G. and Pickett, K.E. (2006), "Income inequality and population health: a review and explanation of the evidence", Social Science and Medicine, Vol. 62 No. 7, pp. 1768-1784.

Wilkinson, R.G. and Pickett, K.E. (2009a), The Spirit Level: Why More Equal Societies Almost Always Do Better, Penguin, London.

Wilkinson, R.G. and Pickett, K.E. (2009b), "Income inequality and social dysfunction", Annual Review of Sociology, Vol. 35 No. 1, pp. 493-511.

Yabuuchi, S. (1999), "Foreign direct investment, urban unemployment and welfare", The Journal of International Trade and Economic Development, Vol. 8 No. 4, pp. 359-371.

Zhao, S.X. and Zhang, L. (2007), "Foreign direct investment and the formation of global city-regions in China”, Regional Studies, Vol. 41 No. 7, pp. 979-994.

\section{About the authors}

Rajneesh Narula is the John H. Dunning Chair of International Business Regulation at the Henley Business School, University of Reading, UK. His research and consulting have focused on the role of multinational firms in development, innovation and industrial policy, R\&D alliances and outsourcing. He has published numerous articles in international reputable journals, as well as book chapters and books.

Khadija van der Straaten is a $\mathrm{PhD}$ Candidate at the University of Amsterdam, Amsterdam Business School and lecturer at the Rotterdam Business School, Rotterdam University of Applied Sciences, both in the Netherlands. Her research interests include sustainable development, inequality and gender issues. Her research has appeared in the Journal of International Business Studies. Khadija van der Straaten is the corresponding author and can be contacted at: p.r.vanderstraaten@ uva.nl

For instructions on how to order reprints of this article, please visit our website: www.emeraldgrouppublishing.com/licensing/reprints.htm Or contact us for further details: permissions@emeraldinsight.com 